\title{
Analisis Dampak Implementasi Kebijakan Penyaluran Dana Bantuan Operasional Sekolah (Bos)
}

\author{
(Studi di SMA Negeri 1 Halmahera Utara)
}

\author{
Deiby Christiana Tinggogoy \\ Program Studi Ilmu Administrasi Negara, Fakultas Ilmu Sosial dan Humaniora \\ Universitas Halmahera \\ Email: christianadeiby@gmail.com
}

\begin{abstract}
Abstraksi
Proses penyaluran dana BOS dinilai belum terimplementasi dengan baik sehingga muncullah keluhan dari sekolah-sekolah. SMA Negeri 1 Halut misalnya menjelaskan berbagai dampak yang muncul akibat keterlambatan pencairan. Sesuai dengan Peraturan Menteri Pendidikan dan Kebudayaan Republik Indonesia Nomor 3 Tahun 2019 tentang Petunjuk Teknis Bantuan Operasional Sekolah Reguler, bahwa penyaluran dana BOS Reguler di awal triwulan I (untuk penyaluran triwulanan) dan semester I (untuk penyaluran semesteran), namun kenyataannya selalu mengalami keterlambatan setiap tahunnya. Tujuan penelitian untuk menganalisis: 1). Faktor-faktor apa saja yang mempengaruhi keterlambatan proses pencairan dana BOS; dan 2). Seperti apakah dampak yang muncul karena keterlambatan dana yang masuk di SMA Negeri 1 Halmahera Utara. Ada beberapa variabel penting yang harus diperhatikan agar kebijakan dapat terimplemtasi dengan baik.
\end{abstract}

Kata kunci: Penyaluran dana BOS, implementasi kebijakan, kelompok sasaran 


\section{Latar belakang}

Dalam Peraturan Menteri Pendidikan dan Kebudayaan Republik Indonesia Nomor 3 Tahun 2019 tentang Petunjuk Teknis Bantuan Operasional Sekolah Reguler pada pasal 1 ayat (11) dijelaskan bahwa Bantuan Operasional Sekolah Reguler yang selanjutnya disingkat BOS Reguler adalah program Pemerintah Pusat untuk penyediaan pendanaan biaya operasi personalia dan nonpersonalia bagi Sekolah yang bersumber dari dana alokasi khusus nonfisik. Selanjutnya, pada pasal 3 dijelaskan juga bahwa BOS Reguler bertujuan untuk membantu biaya operasional penyelenggaraan pendidikan di Sekolah. Dengan demikian, BOS Reguler dialokasikan untuk penyelenggaraan pendidikan di Sekolah. Penyelenggaraan pendidikan merupakan salah satu prioritas pembangunan nasional, untuk itu pemerintah pusat memberikan bantuan dana sehingga hal tersebut diharapkan dapat mendorong pemerintah daerah dalam menyelenggarakan pendidikan bagi masyarakat. Dengan masyarakat memperoleh pendidikan yang baik, tentu akan mengurangi pengangguran di Negara ini sehingga membantu Negara berkembang ke arah yang lebih baik dalam semua aspek kehidupan. Hal ini jika terus diperhatikan oleh pemerintah, maka bukan tidak mungkin Negara ini kedepanya akan dapat bersaing dengan Negara maju.
Sesuai dengan kebijakan pemerintah yang diatur dalam Peraturan Menteri di atas, dijelaskan juga bahwa tim bantuan operasional sekolah regular terdiri dari tim BOS regular Pusat, Provinsi, dan Kabupaten/kota. Selanjutnya, tim BOS reguler Kabupaten/kota bertanggung jawab terhadap proses pendataan pada SD dan SMP. Sementara itu, tim BOS reguler Provinsi bertanggung jawab terhadap proses pendataan pada SMA dan SMK. Selain itu, dalam proses pencairan dijelaskan bahwa penetapan alokasi BOS Reguler tiap Sekolah didasarkan pada data hasil batas waktu akhir pendataan (cut off) Dapodik berikut: 1) cut off tanggal 31 Januari; dan 2) cut off tanggal 31 Oktober. Pada tiap tanggal cut off, tim BOS Reguler provinsi mengunduh data Sekolah seluruh jenjang sebagai dasar penyaluran dana BOS Reguler sesuai dengan ketentuan cut off melalui laman yang disediakan Kementerian. Selanjutnya, alokasi BOS Reguler untuk Sekolah ditetapkan dengan ketentuan sebagai berikut yaitu pada Triwulan I dan semester I: a) alokasi sementara tiap Sekolah untuk penyaluran triwulan I (untuk penyaluran triwulanan) dan semester I (untuk penyaluran semesteran) didasarkan pada hasil cut off tanggal 31 Oktober tahun anggaran sebelumnya; b) Berdasarkan data cut off tanggal 31 Oktober ini, provinsi menyalurkan dana BOS Reguler ke tiap Sekolah di awal triwulan I (untuk 
penyaluran triwulanan) dan semester I (untuk penyaluran semesteran) sesuai dengan ketentuan peraturan perundang-undangan; c) Alokasi final tiap Sekolah untuk triwulan I dan semester I didasarkan pada hasil cut off tanggal 31 Januari; d) Berdasarkan data cut off tanggal 31 Januari ini, provinsi menghitung lebih kurang penyaluran dana BOS Reguler di awal triwulan I (untuk penyaluran triwulanan) dan semester I (untuk penyaluran semesteran) untuk dikompensasikan dalam penyaluran dana BOS Reguler triwulan II dan semester II sesuai dengan ketentuan peraturan perundang-undangan.

Maluku Utara adalah salah satu Provinsi yang ada di Indonesia dan terdiri dari 10 Kabupaten/kota. Halmahera Utara adalah salah satu Kabupaten yang ada di Provinsi Maluku Utara, yang memiliki SMA/SMK 55 Sekolah negeri maupun swasta dan salah satunya adalah SMA Negeri 1 Halmahera Utara yang berada di kecamatan Tobelo. SMA Negeri 1 Halmahera Utara adalah salah satu sekolah yang mengeluh terkait proses pencairan dana BOS, hal ini karena proses pencairan dinilai tidak sesuai dengan prosedur yang ada. Hal ini berdampak pada keuangan sekolah yang tidak stabil sehingga tentunya adanya keterlambatan pembayaran honor guru honorer dan tentunya untuk biaya operasional sekolah. Para staf dan pengajar yang ada menegeluhkan kenapa kebijakan yang ada tidak dapat terimplementasi dengan baik. Keterlambatan proses pencairan dana BOS menjadi permasalahan yang krusial karena sudah terjadi bertahun-tahun. Pada tahun 2017 misalnya dana yang diterima masuk pada bulan juli padahal seharusnya sudah cair pada bulan februari yaitu sesuai dengan peraturan yang ada. Dimana, pencairan dana untuk triwulan 1 harus berdasarkan pada hasil cut off tanggal 31 Januari, yang artinya seharusnya dana cair pada bulan februari tetapi kenyataannya dana masuk pada bulan juli, tentu saja hal ini tidak sesuai dengan kebijakan yang ada sehingga berdampak tidak baik karena kebutuhan yang ada tidak terpenuhi.

Kebijakan publik menurut Carl Friedrich merupakan suatu tindakan yang mengarah pada tujuan yang diusulkan oleh seseorang, kelompok atau pemerintah dalam lingkungan tertentu sehubungan dengan adanya hambatan-hambatan tertentu seraya mencari peluang-peluang untuk mencapai tujuan tertentu (Indiahono, 2009: 18). Selanjutnya, Indiahono juga menjelaskan bahwa kebijakan publik adalah segala aktivitas yang dilakukan oleh pemerintah untuk memecahkan masalah publik yang dihadapi. Dengan membawa kebijakan publik dalam ranah upaya memecahkan masalah publik maka warna administrasi publik akan lebih terasa kental. Dengan demikian, kebijakan publik diarahkan untuk memecahkan masalah publik untuk memenuhi kepentingan dan penyelenggaraan urusan-urusan publik. kebijakan publik yang telah dibuat dan kemudian ditetapkan, hendaknya diimplementasikan dengan baik sehingga kebijakan yang telah ditetapkan 
dinyatakan berhasil. Implementasi menurut Gordon berkenaan dengan berbagai kegiatan yang diarahkan pada realisasi program (Keban, 2014: 76). Selanjutnya, Keban menjelaskan bahwa dalam hal ini administrator mengatur cara untuk mengorganisir, menginterpretasikan dan menerapkan kebijakan yang telah diseleksi. Mengorganisir berarti mengatur sumberdaya, unitunit dan metode-metode untuk melaksanakan program. Melakukan interpretasi berkenaan dengan menterjemahkan bahasa atau istilah-istilah program kedalam rencana-rencana dan petunjukpetunjuk yang dapat diterima. Menerapkan berarti menggunakan instrument-instrumen, mengerjakan atau memberikan pelayanan rutin, melakukan pembayaran-pembayaran. Dengan kata lain, implementasi merupakan tahap merealisasi tujuantujuan program. Dengan demikian, sangat perlu memperhatikan persiapan implementasi yaitu memikirkan dan menghitung secara matang berbagai kemungkinan keberhasilan dan kegagalan, termasuk hambatan atau peluangpeluang yang ada dan kemampuan organisasi yang diserahi tugas untuk melaksanakan program.

Kebijakan yang telah ditetapkan oleh pemerintah, merupakan harapan masyarakat agar dapat terimplementasi dengan baik sehingga dapat berdampak baik bagi kehidupan masyarakat. Kebijakan yang tidak terimplementasi dengan baik tentu akan menimbulkan masalah karena apa yang menjadi harapan masyarakat tidak terpenuhi. Permasalahan yang perlu untuk dikaji yaitu: 1).
Faktor-faktor apa saja yang mempengaruhi keterlambatan proses pencairan dana BOS?; dan 2). Seperti apakah dampak yang muncul karena keterlambatan dana yang masuk di SMA Negeri 1 Halmahera Utara?. Dengan demikian, penelitian ini dilakukan untuk mengkaji dan memberikan rekomendasi pada pihak terkait sehingga dapat menemukan solusi terbaik. Melihat permasalahan ini sehingga penelitian menarik untuk dilakukan.

\section{Tinjauan Pustaka}

\section{Implementasi Kebijakan}

Kebijakan oleh Graycar dapat dipandang dari perspektif filosofis, produk, proses, dan kerangka kerja (Keban, 2014: 59). Sebagai suatu konsep "filosofis", kebijakan dipandang sebagai serangkaian prinsip, atau kondisi yang diinginkan; sebagai suatu "produk", kebijakan diartikan sebagai serangkaian kesimpulan atau rekomendasi; sebagai suatu "proses", kebijakan menunjuk pada cara dimana melalui cara tersebut suatu organisasi dapat mengetahui apa yang diharapkan darinya yaitu program dan mekanisme dalam mencapai produknya; dan sebagai suatu " kerangka kerja", kebijakan merupakan suatu proses tawar menawar dan negosiasi untuk merumuskan isu-isu dan metode implementasinya. Selanjutnya, Hogwood dan Gunn, juga menjelaskan bahwa terdapat serangkaian pengertian tentang kebijakan yang menunjukkan makna yang berbeda-beda. Kebijakan dapat diartikan sebagai "label bagi suatu bidang kegiatan” seperti kebijakan ekonomi, 
kebijakan industri, kebijakan ketertiban dan hukum; dapat juga diartikan sebagai suatu "ekspresi tentang tujuan umum atau kondisi yang diinginkan", seperti menciptakan pekerjaan sebanyak mungkin, mempromosi demokratisasi melalui desentralisasi, atau membasmi akar kemiskinan; kebijakan juga dapat diartikan sebagai usulan atau proposal khusus seperti melakukan devaluasi nilai uang sebesar $10 \%$ atau memberikan pendidikan dasar secara gratis; kebijakan juga bisa dilihat sebagai keputusan pemerintah seperti keputusan presiden; juga dapat dilihat sebagai otorisasi formal seperti ketetapan parlemen (Keban, 2014: 60).

Menurut Dunn bahwa dalam rangka memecahkan masalah ada beberapa tahap penting antara lain yaitu penetapan agenda kebijakan (agenda setting), formulasi kebijakan (policy formulation), adopsi kebijakan (policy adoption), implementasi kebijakan (policy implementation), dan penilaian kebijakan (policy assessment). Pada tahap penetapan agenda kebijakan, ditentukan apa yang menjadi masalah publik yang perlu dipecahkan. Hakekat permasalahan ditentukan melalui suatu prosedur yang seringkali dikenal dengan nama problem structuring. Pada tahap formulasi kebijakan, para analisis mengidentifikasi kemungkinan kebijakan yang dapat digunakan dalam memecahkan masalah. Untuk itu, diperlukan sutu prosedur yang disebut forecasting, dimana konsekuensi dari masing-masing kemungkinan kebijakan dapat diungkapkan.
Adopsi kebijakan merupakan tahap berikutnya, dimana ditentukan pilihan kebijakan melalui dukungan para administrator dan legislatif. Tahap ini ditentukan setelah melalui suatu proses rekomendasi. Implementasi kebijakan merupakan suatu tahap dimana kebijakan yang telah diadopsi tersebut dilaksanakan oleh unit-unit administratif tertentu dengan memobilisasi dana dan sumberdaya yang ada. pada tahap ini proses monitoring dilakukan. Dan tahap terakhir adalah tahap penilaian kebijakan dimana berbagai unit yang telah ditentukan melakukan penilaian tentang apakah semua proses implementasi telah sesuai dengan apa yang telah ditentukan atau tidak. Dalam tahap tersebut proses evaluasi diterapkan (Keban, 2014:67).

Implementasi kebijakan adalah merealisasi apa yang menjadi tujuan-tujuan program. Menurut George C. Edward III bahwa ada empat variabel yang berperan penting dalam pencapaian keberhasilan implementasi (Indiahono: 2009: 31) yaitu:

1). Komunikasi, yaitu menunjuk bahwa setiap kebijakan akan dapat dilaksanakan dengan baik jika terjadi komunikasi efektif antara pelaksana program (kebijakan) dengan para kelompok sasaran (target group). Tujuan dan sasaran dari program/kebijakandapat disosialisasikan secara baik sehingga dapat menghindari adanya distorsi atas kebijakan dan program. 
2). Sumberdaya, yaitu menunjuk setiap kebijakan harus didukung oleh submerdaya yang memadai, baik sumber daya manusia maupun sumber daya finansial. Sumberdaya manusia adalah kecukupan baik kualitas maupun kuantitas implementor yang dapat melingkupi seluruh kelompok sasaran. Sumberdaya finansial adalah kecukupan modal investasi atas sebuah program/kebijakan. Keduanya harus diperhatikan dalam implementasi program/kebijakan pemerintah.

3). Disposisi, menunjuk pada karakteristik yang menempel erat kepada implementor kebijakan/program. Karakter yang penting dimiliki oleh implementor adalah kejujuran, komitmen, dan demokratis. Implementor yang memiliki komitmen tinggi dan jujur akan senantiasa bertahan diantara hambatan yang ditemui dalam program/kebijakan.

4). Struktur birokrasi, menunjuk bahwa struktur birokrasi menjadi penting dalam implementasi kebijakan. Aspek struktur birokrasi ini mencakup dua hal yaitu penting yaitu pertama adalah mekanisme, dan sturuktur organisasi pelaksana sendiri. Mekanisme implementasi program biasanya sudah ditetapkan melalui standar operating procedur (SOP) yang dicantumkan dalam kebijakan. SOP yang baik mencantumkan kerangka kerja yang jelas, sistematis, tidak berbelit dan mudah dipahami oleh siapapun karena akan menjadi acuan dalam bekerjanya implementor. Selanjutnya, struktur organisasi pelaksana harus dapat menjamin adanya pengambilan keputusan atas kejadian luar biasa dalam program secara cepat.

\section{Pemerintah Daerah}

Istilah government (pemerintah), secara epistemology berasal dari kata "governor" yang diambil dari Bahasa Yunani dengan padanana kata steering-steersman (yang mengarahkan) sehinggga menurut Wiener secara umum pemerintah adalah merupakan istilah yang dipakai untuk menunjuk Lembaga yang mengarahkan kehidupan masyarakat (Setiyono, 2014: 11). Selanjutnya, dijelaskan pula bahwa secara konsepsional, pemerintah adalah Lembaga yang dibentuk untuk mewujudkan cita-cita masyarakat suatu bangsa, membuat dan melaksanakan keputusan bersama untuk mencapai cita-cita itu. Pemerintah mendapatkan mandat yang otoritatif untuk mendayagunakan sumber-sumber daya yang ada pada masyarakat untuk melaksanakan tugas itu. Di Indonesia menggunakan sistem otonomi daerah yang artinya adanya hak daerah dan masyarakat untuk memperoleh keleluasaan bergerak dan kesempatan untuk menggunakan prakarsa sendiri, atas segala macama nilai dan potensi yang 
dikuasai untuk mengurus kepentingan publik, baik yang menyangkut pemberian pelayanan kepada masyarakat melalui pemberian fasilitas dan bimbingan terhadap masyarakat, maupun untuk meningkatkan kesejahteraan rakyat melalui pelaksanaan pembangunan. Otonomi daerah kemudian, melahirkan desentralisasi yang merupakan suatu kepercayaan pemerintah pusat dengan menyerahkan urusan kepada daerah dalam bentuk hak, kewajiban, wewenang, mengatur, mengurus dan menyelenggarakan urusan atau kegiatan pmerintahan tersebut. Pemerintah daerah adalah penyelenggara pemerintahan. Pemerintahan daerah dalam UU Nomor 23 Tahun 2014 diartikan sebagai penyelenggaraan urusan pemerintahan oleh pemerintah daerah dan DPRD menurut asas otonomi dan tugas pembantuan dengan prinsip otonomi seluas-luasnya dalam sistem dan prinsip Negara Kesatuan Republik Indonesia sebagaimana dimaksud dalam undang-undang Dasar Negara Republik Indonesia Tahun1945 (Arenawati, 2014: 9). Hal ini berarti pemerintah dengan kewenangan yang diberikan sudah seharusnya dapat melaksankan tugasnya dengan baik sehingga dapat memberikan kesejahteraan kepada masyarakat. Kebijakan yang telah ditetapkan oleh pemerintah pusat sudah seharusnya diimplementasikan dengan baik oleh pemerintah daerah sehingga kebijakan dapat berjalan dengan baik. Itu artinya kebijkan/program harus benar-benar tetap sasaran sehingga dapat membangun kepercayaan kelompok sasaran terhadap kebijakan yang telah ditetapkan.

\section{Petunjuk Teknis Bantuan Operasional Sekolah Reguler}

Dalam Peraturan Menteri Pendidikan dan Kebudayaan Republik Indonesia Nomor 3 Tahun 2019 tentang Petunjuk Teknis Bantuan Operasional Sekolah Reguler (juknis) pada pasal 1 ayat (11) menyatakan bahwa Bantuan Operasional Sekolah Reguler yang selanjutnya disingkat BOS Reguler adalah program Pemerintah Pusat untuk penyediaan pendanaan biaya operasi personalia dan nonpersonalia bagi Sekolah yang bersumber dari dana alokasi khusus nonfisik. Selanjutnya, pada pasal 3 dijelaskan juga bahwa BOS Reguler bertujuan untuk membantu biaya operasional penyelenggaraan pendidikan di Sekolah. Selanjutnya, dijelaskan bahwa menjadi tujuan umum pemberian dana BOS yaitu: 1). Membantu pendanaan biaya operasi dan personalia sekolah; 2) meringankan beban biaya operasi sekolah bagi peserta didik pada sekolah yang diselenggarakan oleh masyarakat; 3). Meningkatkan kualitas proses pembelajaran di sekolah. Sementara itu, yang menajadi tujuan khusus yaitu: 1). BOS Reguler SD dan SMP bertujuan untuk membebaskan pungutan peserta didik yang orang tua/walinya tidak mampu pada SD dan SMP yang diselenggarakan oleh masyarakat; 2). BOS Reguler pada SMA dan SMK bertujuan untuk membebaskan pungutan dan/atau membantu tagihan biaya di SMA dan SMK bagi 
peserta didik yang orang tua/walinya tidak mampu dalam rangka memperoleh layanan pendidikan yang terjangkau dan bermutu; 3). BOS Reguler pada SDLB, SMPLB, SMALB, dan SLB bertujuan untuk: a. meningkatkan aksesibilitas belajar bagi peserta didik penyadang disabilitas pada SDLB, SMPLB, SMALB, dan SLB dan atau, b. memberikan kesempatan yang setara bagi peserta didik penyandang disabilitas yang orang tua/walinya tidak mampu untuk mendapatkan layanan pendidikan yang terjangkau dan bermutu pada SDLB, SMPLB, SMALB dan SLB baik yang diselenggarakan masyarakat mamupun pemerintah. Adapun yang menjadi sasaran yaitu sekolah yang diselenggarakan oleh pemerintah daerah maupun masyarakat penyelenggara pendidikan yang telah terdata dalam dapodik. Bagi sekolah yang diselenggarakan oleh masyarakat telah memiliki izin operasional. Waktu penyaluran dilakukan tiap triwulan. Bagi wilayah dengan geografis yang sulit dijangkau penyaluran dana BOS reguler dilakukan tiap semester.

Sesuai dengan kebijakan pemerintah yang diatur dalam Peraturan Menteri di atas, dijelaskan juga bahwa tim bantuan operasional sekolah regular terdiri dari tim BOS regular Pusat, Provinsi, dan Kabupaten/kota. Selanjutnya, tim BOS reguler Kabupaten/kota bertanggung jawab terhadap proses pendataan pada SD dan SMP. Sementara itu, tim BOS reguler Provinsi bertanggung jawab terhadap proses pendataan pada SMA dan SMK. Selain itu, dalam proses pencairan dijelaskan bahwa penetapan alokasi BOS Reguler tiap Sekolah didasarkan pada data hasil batas waktu akhir pendataan (cut off) Dapodik berikut: 1) cut off tanggal 31 Januari; dan 2) cut off tanggal 31 Oktober. Pada tiap tanggal cut off, tim BOS Reguler provinsi mengunduh data Sekolah seluruh jenjang sebagai dasar penyaluran dana BOS Reguler sesuai dengan ketentuan cut off melalui laman yang disediakan Kementerian. Selanjutnya, alokasi BOS Reguler untuk Sekolah ditetapkan dengan ketentuan sebagai berikut yaitu pada Triwulan I dan semester I: a) alokasi sementara tiap Sekolah untuk penyaluran triwulan I (untuk penyaluran triwulanan) dan semester I (untuk penyaluran semesteran) didasarkan pada hasil cut off tanggal 31 Oktober tahun anggaran sebelumnya; b) Berdasarkan data cut off tanggal 31 Oktober ini, provinsi menyalurkan dana BOS Reguler ke tiap Sekolah di awal triwulan I (untuk penyaluran triwulanan) dan semester I (untuk penyaluran semesteran) sesuai dengan ketentuan peraturan perundang-undangan; c) Alokasi final tiap Sekolah untuk triwulan I dan semester I didasarkan pada hasil cut off tanggal 31 Januari; d) Berdasarkan data cut off tanggal 31 Januari ini, provinsi menghitung lebih kurang penyaluran dana BOS Reguler di awal triwulan I (untuk penyaluran triwulanan) dan semester I (untuk penyaluran semesteran) untuk dikompensasikan dalam penyaluran dana BOS Reguler triwulan II dan semester II sesuai dengan ketentuan peraturan perundang-undangan 


\section{Pendidikan}

Meningkatkan akses dan mutu pendidikan adalah salah satu prioritas pembangunan nasional. Dalam Undang-Undang Nomor 20 tahun 2003 tentang sistem pendidikan nasional pada pasal 1 ayat (1) dijelaskan pendidikan adalah usaha sadar dan terencana untuk mewujudkan suasana belajar dan proses pembelajaran agar peserta didik secara aktif mengembangkan potensi dirinya untuk memiliki kekuatan spiritual keagamaan, pengendalian diri, kepribadian, kecerdasaan, akhlak mulia, serta keterampilan yang diperlukan dirinya, masyarakat, bangsa, dan negara. Ayat (2) menjelaskan pendidikan nasional adalah pendidikan yang berdasarkan Pancasila dan Undang-Undang Dasar Negara Republik Indonesia tahun 1945 yang beraakar pada nilai-nilai agama, kebudayaan nasional indonesia, dan tanggap terhadap tuntutan perubahan zaman. Pada pasal 3 dijelaskan bahwa Pendidikan nasional berfungsi mengembangkan kemampuan dan membentuk watak serta peradaban bangsa yang bermartabat dalam rangka mencerdaskan kehidupan bangsa, bertujuan untuk berkembangnya potensi peserta didik agar menjadi manusia yang beriman dan bertakwa kepada Tuhan Yang Maha Esa, berakhlak mulia, sehat, berilmu, cakap, kreatif, mandiri, dan menjadi warga negara yang demokratis serta bertanggung jawab. Selain itu, secara tegas juga nyatakan pada pasal 5 bahwa (1) Setiap warga negara mempunyai hak yang sama untuk memperoleh pendidikan yang bermutu, (2)
Warga negara yang memiliki kelainan fisik, emosional, mental, intelektual, dan/atau sosial berhak memperoleh pendidikan khusus, (3) Warga negara di daerah terpencil atau terbelakang serta masyarakat adat yang terpencil berhak memperoleh pendidikan layanan khusus, (4) Warga negara yang memiliki potensi kecerdasan dan bakat istimewa berhak memperoleh pendidikan khusus, (5) Setiap warga negara berhak mendapat kesempatan meningkatkan pendidikan sepanjang hayat. Selain, itu dalam undang-undang ini juga dijelaskan tugas utama pemerintah yaitu pada pasal 11 bahwa (1) Pemerintah dan Pemerintah Daerah wajib memberikan layanan dan kemudahan, serta menjamin terselenggaranya pendidikan yang bermutu bagi setiap warga negara tanpa diskriminasi, (2) Pemerintah dan Pemerintah Daerah wajib menjamin tersedianya dana guna terselenggaranya pendidikan bagi setiap warga negara yang berusia tujuh sampai dengan lima belas tahun.

\section{Metode}

Jenis penelitian yang diapakai yaitu kualitatif, metode ini mencoba mengerti makna suatu kejadian atau peristiwa dengan mencoba bereinteraksi dengan orang-orang dalam situasi/fenomena tersebut (Yusuf, 2014:328). Teknik pengumpulan data dengan melakukan wawancara, observasi dan dokumentasi.

\section{Hasil dan Pembahasan}




\section{Gambaran Umum sekolah}

Maluku Utara adalah salah satu Provinsi yang ada di Indonesia dan terdiri dari 10 Kabupaten/kota. Halmahera Utara adalah salah satu Kabupaten yang ada di Provinsi Maluku
Utara, yang memiliki SMA/SMK 55 Sekolah negeri maupun swasta dan salah satunya adalah SMA Negeri 1 Halmahera Utara yang berada di kecamatan Tobelo. Dengan posisi geografis 1,7254 lintang dan 128,0073 Bujur. Dengan rekapitulasi data sebagai berikut:

\begin{tabular}{|l|l|c|c|c|c|}
\hline \multicolumn{1}{|c|}{ 1. Data PTK dan PD } \\
\hline No. & \multicolumn{1}{|c|}{ Uraian } & Guru & Tendik & PTK & PD \\
\hline 1. & Laki-laki & 19 & 4 & 23 & 475 \\
\hline 2. & perempuan & 23 & 3 & 26 & 588 \\
\hline \multicolumn{2}{|c|}{ Total } & 42 & 7 & 49 & 1063 \\
\hline
\end{tabular}

Keterangan:

- Perhitungan jumlah PTK adalah yang sudah mendapat penugasan, berstatus aktif dan terdaftar

- Singkatan:

1. $\mathrm{PTK}=$ Guru ditambah tendik

2. $P D=$ Peserta Didik

\section{Data sarpras}

\begin{tabular}{|l|l|c|}
\hline No. & \multicolumn{1}{|c|}{ Uraian } & Jumlah \\
\hline 1. & Ruang kelas & 20 \\
\hline 2. & Ruang Lab & 4 \\
\hline 3. & Ruang perpus & 1 \\
\hline \multicolumn{2}{|c|}{ Total } & 25 \\
\hline
\end{tabular}

\section{Data rombongan belajar}

\begin{tabular}{|c|c|c|c|c|}
\hline No. & Uraian & Detail & Jumlah & Total \\
\hline \multirow[t]{2}{*}{1.} & Kelas 10 & $\mathrm{~L}$ & 144 & \multirow[t]{2}{*}{350} \\
\hline & & $\mathrm{P}$ & 206 & \\
\hline \multirow[t]{2}{*}{2.} & Kelas 11 & $\mathrm{~L}$ & 176 & \multirow[t]{2}{*}{363} \\
\hline & & $\mathrm{P}$ & 187 & \\
\hline \multirow[t]{2}{*}{3.} & Kelas 12 & $\mathrm{~L}$ & 155 & \multirow[t]{2}{*}{350} \\
\hline & & $P$ & 195 & \\
\hline
\end{tabular}

Faktor yang mempengaruhi keterlambatan proses pencairan dana BOS 
Dalam Peraturan Menteri Pendidikan dan Kebudayaan Republik Indonesia Nomor 3 Tahun 2019 tentang Petunjuk Teknis Bantuan Operasional Sekolah Reguler pada pasal 1 ayat (11) dijelaskan bahwa Bantuan Operasional Sekolah Reguler yang selanjutnya disingkat BOS Reguler adalah program Pemerintah Pusat untuk penyediaan pendanaan biaya operasi personalia dan nonpersonalia bagi Sekolah yang bersumber dari dana alokasi khusus nonfisik. Selanjutnya, dijelaskan juga bahwa tujuan Umum BOS Reguler adalah: 1). Membantu pendanaan biaya operasi dan nonpersonalia Sekolah; 2). Meringankan beban biaya operasi Sekolah bagi peserta didik pada Sekolah yang diselenggarakan oleh masyarakat; dan 3). Meningkatkan kualitas proses pembelajaran di Sekolah. Selain itu, yang menjadi tujuan khusus dari pemberian dana BOS Reguler pada SMA dan SMK bertujuan untuk membebaskan pungutan dan/atau membantu tagihan biaya di SMA dan SMK bagi peserta didik yang orangtua/walinya tidak mampu dalam rangka memperoleh layanan pendidikan yang terjangkau dan bermutu. Selanjutnya, untuk penyaluran dana BOS Reguler dilakukan tiap triwulan.

Dalam proses pencairan dijelaskan bahwa penetapan alokasi BOS Reguler tiap Sekolah didasarkan pada data hasil batas waktu akhir pendataan (cut off) Dapodik berikut: 1) cut off tanggal 31 Januari; dan 2) cut off tanggal 31 Oktober. Pada tiap tanggal cut off, tim BOS Reguler provinsi mengunduh data Sekolah seluruh jenjang sebagai dasar penyaluran dana BOS Reguler sesuai dengan ketentuan cut off melalui laman yang disediakan Kementerian. Selanjutnya, alokasi BOS Reguler untuk Sekolah ditetapkan dengan ketentuan sebagai berikut yaitu pada Triwulan I dan semester I: a) alokasi sementara tiap Sekolah untuk penyaluran triwulan I (untuk penyaluran triwulanan) dan semester I (untuk penyaluran semesteran) didasarkan pada hasil cut off tanggal 31 Oktober tahun anggaran sebelumnya; b) Berdasarkan data cut off tanggal 31 Oktober ini, provinsi menyalurkan dana BOS Reguler ke tiap Sekolah di awal triwulan I (untuk penyaluran triwulanan) dan semester I (untuk penyaluran semesteran) sesuai dengan ketentuan peraturan perundang-undangan; c) Alokasi final tiap Sekolah untuk triwulan I dan semester I didasarkan pada hasil cut off tanggal 31 Januari; d) Berdasarkan data cut off tanggal 31 Januari ini, provinsi menghitung lebih kurang penyaluran dana BOS Reguler di awal triwulan I (untuk penyaluran triwulanan) dan semester I (untuk penyaluran semesteran) untuk dikompensasikan dalam penyaluran dana BOS Reguler triwulan II dan semester II sesuai dengan ketentuan peraturan perundang-undangan.

Kebijakan oleh Graycar dapat dipandang dari perspektif filosofis, produk, proses, dan kerangka kerja (Keban, 2014: 59). Sebagai suatu konsep "filosofis", kebijakan dipandang sebagai serangkaian prinsip, atau kondisi yang diinginkan; sebagai suatu "produk", kebijakan diartikan 
sebagai serangkaian kesimpulan atau rekomendasi; sebagai suatu "proses", kebijakan menunjuk pada cara dimana melalui cara tersebut suatu organisasi dapat mengetahui apa yang diharapkan darinya yaitu program dan mekanisme dalam mencapai produknya; dan sebagai suatu " kerangka kerja", kebijakan merupakan suatu proses tawar menawar dan negosiasi untuk merumuskan isu-isu dan metode implementasinya. Menurut Gordon bahwa Implementasi berkenaan dengan berbagai kegiatan yang diarahkan pada realisasi program (Keban, 2014: 76). Selanjutnya, keban menambahkan bahwa dalam hal ini administrator mengatur cara untuk mengorganisir, menginterpretasikan dan menerapkan kebijakan yang telah diseleksi. Mengorganisir berarti mengatur sumberdaya, unitunit, dan metode-metode untuk melaksanakan program. Melakukan interpretasi berkenaan dengan menterjemahkan bahasa atau istilah-istilah program kedalam rencana-rencana dan petunjukpetunjuk yang dapat diterima. Menerapkan berarti menggunakan instrument-instrumen, mengerjakan atau memberikan pelayanan rutin, melakukan pembayaran-pembayaran atau dengan kata lain, implementasi merupakan tahap merealisasi tujuantujuan program. Ada empat variabel yang berperan penting dalam pencapaian keberhasilan implementasi yaitu: 1). komunikasi, 2). sumberdaya, 3). Disposisi, 4). Struktur birokrasi. Jika, dilihat dari keempat variabel ini maka, kebijakan terkait penyaluran dana BOS belum terimplementasi dengan baik, hal ini terlihat dengan adanya keluhan-keluhan dari sekolahsekolah di Kabupaten Halmahera Utara, salah satunya sekolah SMA Negeri 1 Halmahera Utara.

Kebijakan penyaluran dana BOS dinilai belum terimplementasi dengan baik karena jika dianalisis berdasarkan empat variabel penting dalam implementasi maka dapat diketahui faktorfaktor yang mempengaruhi keterlambatan proses penyaluran dana yaitu dari segi:

1). Komunikasi: menunjuk bahwa setiap kebijakan akan dapat dilaksanakan dengan baik jika terjadi komunikasi efektif antara pelaksana program dengan para kelompok sasaran. Dari hasil yang didapatkan bahwa komunikasi terjadi kurang efektif karena ketika ada keluhan dari sekolah-sekolah terkait keterlambatan penyaluran dana yang berdampak buruk bagi sekolah, tetapi keluhan tersebut tidak ditindaklanjuti sehingga permasalahan ini terus terjadi. Paling parah pada tahun 2017, dana yang diterima masuk pada bulan juli padahal seharusnya sudah cair pada bulan februari yaitu sesuai dengan peraturan yang ada. Dimana, pencairan dana untuk triwulan 1 harus berdasarkan pada hasil cut off tanggal 31 Januari, yang artinya seharusnya dana cair pada bulan februari tetapi kenyataannya dana masuk pada bulan juli. Keluhan ini sudah disampaikan oleh pihak sekolah saat dilaksanakan diklat oleh 
Provinsi tetapi dari pihak Provinsi menyampaikan bahwa banyak sekolah yang terlambat memasukkan laporan sehingga terjadi keterlambatan pencairan. Namun, dari pihak sekolah menyatakan bahwa laporan tidak akan mungkin terlambat jika dana sudah masuk lebih awal.

2). Sumberdaya: menunjuk bahwa tanpa didukung sumberdaya yang memadai, baik itu manusia maupun finansial maka kebijakan yang telah ditetapkan tidak dapat berjalan efektif. Dibutuhkan kecukupan baik kualitas maupun kuantitas implementor yang dapat melingkupi seluruh kelompok sasaran. Maupun dalam finansial yaitu kecukupan modal investasi atas sebuah program/kebijakan. Oleh karena itu, dibutuhkan seorang implementor yang dengan cepat menindaklanjuti setiap keluhan yang masuk sehingga apa yang menjadi tujuan program dalam berjalan dengan efektif. Namun, hal tersebut tidak terjadi sehingga keluhan yang masuk tidak cepat ditanggapi.

3). Disposisi: menunjuk pada sikap demokratis seorang implementor kebijakan/program sehingga meningkatkan kesan baik implementor dan kebijakan dihadapan anggota kelompok sasaran.
Sikap seperti ini akan menurunkan resistensi dari masyarakat dan menumbuhkan rasa percaya dan kepedulian kelompok sasaran terhadap implementor dan program/kebijakan. Dengan adanya keluhan-keluhan yang ada jika ditindaklanjuti dengan baik, maka tentu saja hal ini akan menimbulkan kepedulian kelompok sasaran kepada program yang telah ditetapkan sehingga kelompok sasaran akan semangat dalam menaati peraturan yang telah ditetapkan.

4).Struktur birokrasi: menunjuk bahwa struktur birokrasi menjadi penting dalam implementasi kebijakan. Struktur organisasi pelaksana harus dapat menjamin adanya pengambilan keputusan atas kejadian luar biasa dalam program secara cepat. Dengan menindaklanjuti keluhan secara cepat akan berdampak baik bagi program implementor kebijakan/program, program tersebut, dan juga kepada kelompok sasaran.

\section{Dampak}

Ketika suatu kebijakan diimplementasi, sudah pasti akan memberikan dampak bagi kelompok sasaran dari kebijakan tersebut. Dampak yang diharapkan tentu adalah dampak positif yang dapat membangun kelompok sasaran ke arah yang lebih baik tetapi tidak dapat dipungkiri terkadang dampak yang dirasakan oleh kelompok sasaran 
adalah sebaliknya. Dampak yang dirasakan oleh pihak sekolah di Halmahera Utara, terlebih khusus di SMA Negeri 1 Halmahera Utara adalah dengan keterlambatan penyaluran dana ke sekolah membuat berbagai permasalahan terjadi yaitu antara lain terganggunya pencapaian apa yang menjadi tujuan dari pemberian dana BOS tersebut. Kenyataannya yang terjadi: 1). pihak sekolah harus hutang dulu untuk membayar apa yang menjadi kebutuhan sekolah, 2). terlambat membayar honor guru honorer sebanyak 11 orang, dimana terhitung 5 orang yang sudah menikah sehingga tentu saja mereka sangat membutuhkan honor tersebut untuk membantu perekonomian keluarga, 3). Keterlambatan pengiriman pelaporan sehingga dapat berdampak bagi keterlambatan pada pencairan berikutnya. Begitu banyak masalah yang terjadi sehingga dibutuhkan penanganan yang tepat, agar masalah ini tidak terus terjadi setiap tahun nya.

\section{Kesimpulan}

\section{Faktor yang mempengaruhi}

Faktor yang mempengaruhi keterlambatan proses pencairan adalah: 1). Komunikasi yang ada tidak berjalan efektif, pengeluhan yang masuk tidak ditindaklanjuti dengan cepat dan tepat sehingga berdampak terjadi penggulangan setiap tahunnya, 2). sumberdaya yang ada tidak dipergunakan dengan efektif, 3). Disposisi tidak telalu Nampak dalam menindaklanjuti keluhan- keluhan yang ada, 4). Struktur birokrasi yang kompleks.

\section{Dampak}

Berbagai dampak yang terjadi membuktikan bahwa tidak maksimalnya Pemerintah Daerah dalam menjalankan tugasnya sehingga kebijakan yang telah ditetapkan oleh Pemerintah Pusat tidak berjalan dengan maksimal. Berbagai keluhan yang ada menyatakan bahwa kebijakan belum terimplementasi dengan baik sehingga tujuan dari pemberian dana BOS ke sekolah-sekolah belum seutuhnya tercapai karena permasalahan ini masih terjadi setiap tahunnya.

\section{Saran}

\section{Faktor yang mempengaruhi}

1. Komunikasi antara Pemerintah Pusat, Pemerintah Daerah, pihak sekolah harus lebih ditingkatkan lagi agar tidak terjadi kesalahpahaman. Dengan adanya keluhan, maka Pemerintah Daerah harus cepat menindaklanjuti hal tersebut agar tidak terjadi pengulangan setiap tahunnya dan menurunkan semangat dari pihak sekolah dalam menjalankan kebijakan yang telah ditetapkan.

2. Sumberdaya yang ada harus diberdayakan dengan tepat agar apa yang menjadi tujuan penyaluran dana BOS dapat tercapai.

3. Disposisi haruslah dimiliki sang implementor sehingga dapat meningkatkan 
rasa percaya dan kepedulian kelompok sasaran terhadap implementor dan program/kebijakan. Hal ini tentu berdampak baik karena kelompok sasaran akan mendukung bahkan ikut berpartisipasi dalam kebijakan-kebijakan baru yang nantinya dikeluarkan oleh Pemerintah.

4. Struktur birokrasi hendaklah tidak berbelitbelit, Panjang, dan kompleks. Dengan begitu, apa yang menjadi tujuan kebijakan akan tercapai, kelompok sasaran akan semakin "trust" kepada Pemerintah dan program-programnya, kebijakan-kebijakan akan tepat sasaran dalam rangka pengembangan Negara ini agar lebih baik setiap tahunnya.

\section{Dampak}

Dengan berbagai dampak yang ada, maka Pemerintah harus cepat menindaklanjuti setiap keluhan sehingga memperoleh solusi yang tepat. Pihak sekolah harus terus menyatakan hal-hal apa saja yang harus dilakukan oleh Pemerintah lewat setiap kesempatan yang ada dan menawarkan solusi terbaik bagi pengembangan kebijakan terkait pemberikan dana BOS sehingga dapat meminimalisir permasalahan yang muncul. Dengan demikian, diharapkan lebih baik lagi dalam implementasinya kedepan

\section{Daftar pustaka}

Arenawati. 2014. Administrasi Pemerintahan Daerah: sejarah, konsep, dan penatalaksanaan di Indonesia. Yogyakarta: GRAHA ILMU.

Indiahono, Dwiyanto. 2009. Kebijakan Publik: berbasis dynamic policy analysis. Yogyakarta: Gava Media.

Keban, Yeremias. 2014. Enam Dimensi Strategis Administrasi Publik: konsep, teori, dan isu. Yogyakarta: GAVA MEDIA.

Setiyono, Budi. 2014. Pemerintahan dan Manajemen Sektor Publik: prinsip-prinsip manajemen pengelolaan negara terkini. Jakarta: BUKU SERU

Yusuf, Muri. 2014. METODE PENELITIAN: Kuantitatif, Kualitatif \& Penelitian Gabungan. Jakarta: PRENADAMEDIA GROUP.

Undang-Undang Nomor 20 tahun 2003 tentang sistem pendidikan nasional

Peraturan Menteri Pendidikan dan Kebudayaan Republik Indonesia Nomor 3 Tahun 2019 tentang jugnis 